\title{
Effect of castration on epididymal sperm storage in male musk shrews (Suncus murinus) and mice (Mus musculus)
}

\author{
Emilie F. Rissman and D. Crews* \\ Department of Psychology, University of Virginia, Charlottesville, VA 22903, USA; and *Institute \\ of Reproductive Biology, Department of Zoology, University of Texas, Austin, TX 78712, USA
}

\begin{abstract}
Summary. Reproductively mature male musk shrews and mice were bilaterally castrated. Epididymal sperm numbers and motility were assessed 0, 2, 4 and 6 weeks after surgery. Seminal vesicle weights and plasma concentrations of total androgens were also measured. In male musk shrews, $30 \%$ of the original epididymal sperm numbers were still present 2 weeks after castration and motile spermatozoa were present in 2 of 7 individuals. By 4 and 6 weeks after castration the numbers of spermatozoa remaining declined to about $10 \%$ and no sperm motility was noted. Seminal vesicle weights were maintained at about $30 \%$ of their original size even up to 6 weeks after castration. In male mice, epididymal sperm numbers, seminal vesicle weights, and androgen levels declined more dramatically after castration. Although androgen concentrations in gonadally intact male musk shrews were $\sim 50 \%$ of the values in male mice, after castration the concentrations in musk shrews were $\sim 2$-fold higher than in mice at all times. The results suggest that post-castration retention of epididymal sperm and seminal vesicle weights in the male musk shrew as compared with male mice, is facilitated either by a relatively greater adrenal contribution to circulating androgen levels and/or greater target tissue sensitivity.
\end{abstract}

Keywords: sperm storage; epididymis; androgen; musk shrew; Suncus murinus

\section{Introduction}

Epididymal sperm storage and maturation are dependent on the presence of sufficient concentrations of testicular androgens in most mammalian species (Orgebin-Crist et al., 1975; Bedford, 1979; Brooks, 1981). An evolutionary perspective on the question of the role of the epididymis in sperm maturation and storage has been provided by Bedford (1979). After an examination of a selected group of non-therian vertebrates, several marsupials and 4 eutherian mammals with ascrotal testes, Bedford (1979) concluded that sperm storage in the ascrotal musk shrew (Suncus murinus) might be uniquely androgen-independent. This claim was based on an unpublished finding that epididymal spermatozoa persisted and demonstrated motility for up to 21 days after castration. The following study was conducted to test the intriguing possibility of androgen-independent sperm storage in this mammalian species.

\section{Materials and Methods}

Animals. The musk shrews used in this study were born and raised in our colony. The colony founders were provided in 1985 by Dr G. L. Dryden. They were descended from animals trapped on Guam Island in the early 1960s. The colony is maintained on a light cycle of $14 \mathrm{~h}$ light/day (lights on at 06:00 h EST) at a temperature of $23 \pm 1{ }^{\circ} \mathrm{C}$. Animals are provided with food (Purina Cat Chow and Complete Mink Pellets) and water ad libitum. At weaning (18-20 days of age) male musk shrews were individually housed (cage dimensions: $31 \times 19 \times 12 \mathrm{~cm}$ ) with pine wood shavings and paper towels for bedding. 
The mice used in this study were of the CF-1 strain, purchased from Charles River Laboratories (Wilmington, MA, USA). Animals were housed in conditions identical to those of the musk shrews. The mice were provided with food (Purina Mouse Chow) and water ad libitum.

Experimental design. A total of 28 musk shrews and 25 mice were used. When males reached 60 days of age they were randomly assigned to 1 of 4 conditions. Control males ( 7 of each species) were killed at 60 days of age to provide baseline data on androgen concentrations, epididymal sperm numbers, sperm motility, and seminal vesicle weights in gonadally intact adults. The remaining males were castrated ( 21 musk shrews and 18 mice). These males were killed at 2,4 or 6 weeks after castration (6-7 per group).

Castrations were performed under pentobarbitone sodium anaesthesia $(4 \mathrm{mg} / \mathrm{ml} ; 0 \cdot 1 \mathrm{ml} / 10 \mathrm{~g}$ body weight for both species). Surgery was conducted with care so as not to damage the epididymis or the remaining portions of the male reproductive tract. To prevent sperm leakage, one suture was piaced around the vas deferens just distal to the epididymis. At necropsy, cardiac punctures were performed under ether anaesthesia. Blood was centrifuged and plasma was collected and frozen for later radioimmunoassay. Animals were killed by cervical dislocation under ether anaesthesia. One epididymis from each male was used to examine sperm motility under a light microscope, the other was used to determine sperm number by methods outlined by Kirton et al. (1967). Motility checks were performed by placing the whole epididymis in a small drop of phosphate-buffered saline (PBS) warmed to $37^{\circ} \mathrm{C}$ on a slide. The tissue was minced along the full extent of the epididymis and then pressed gently. This technique has proved reliable for obtaining motile spermatozoa from the epididymis of gonadally intact males. Seminal vesicles were removed, cleaned of excess tissue and weighed.

Androgen radioimmunoassays. Plasma samples were extracted twice with diethyl ether, dried, resuspended in buffer and assayed for total androgens in a single assay. Recovery and intra-assay variability were $99.6 \%$ and $4.6 \%$ respectively. The assay utilized an antibody (purchased from Wien Laboratories Inc., Succasunna, NJ, USA) that reacts $100 \%$ with testosterone, and cross-reacts $63 \%$ with $5 \alpha$-dihydrotestosterone and $47 \%$ with $\Delta$-1-testosterone. The limit of sensitivity for this assay is $10 \mathrm{pg} / \mathrm{ml}$ (for more detailed information see Whittier et al., 1987; Rissman \& Crews, 1988).

Statistics. The results analysed by analyses of variance and Student's $t$ tests.

\section{Results}

Sperm numbers, seminal vesicle weights and plasma androgen concentrations declined after castration of animals of both species (see Table 1). However, the relative decline in sperm number and seminal vesicle weights was not as dramatic in the musk shrew as in the mouse.

Motile spermatozoa were present in all of the gonadally intact musk shrews, but only $29 \%$ of the males ( 2 out of 7 ) retained motile spermatozoa 2 weeks after castration. By 4 or 6 weeks after castration none of the musk shrews had any motile spermatozoa. Sperm numbers and seminal vesicle weights also declined after castration $(\mathrm{F}(3,27)=56.6$ and 44.2 respectively, $P<0.00001)$. At 2 weeks after castration sperm numbers were reduced to $4 \cdot 1 \times 10^{5}(31 \%$ of the original sperm counts) in one epididymis. Sperm numbers continued to drop rapidly thereafter (Table 1). On average, musk shrew seminal vesicles weighed $29.2 \mathrm{mg}$ at 2 weeks after castration. This weight represented only $38 \%$ of that of control gonadally intact animals. Likewise, plasma androgen concentrations dropped from an average of $2.04 \mathrm{ng} / \mathrm{ml}$ before castration to about $100 \mathrm{pg} / \mathrm{ml}$ after castration (at all 3 sampling times). This represented a decline to approximately $4.9 \%$ of the original androgen concentrations after castration.

In male mice motile spermatozoa were nearly absent from the epididymis after castration. Sperm numbers declined sharply in gonadally intact males at 2 weeks after castration $(t(1)=10 \cdot 3$, $P<0.00001$, Table 1). This represented a reduction to $1 \%$ of the original number of epididymal spermatozoa. The reduction was more dramatic in male mice than in musk shrews both because the real numbers of spermatozoa were lower in castrated mice and original sperm counts in gonadally intact mice were higher than those calculated for the musk shrew. Seminal vesicle weights also declined rapidly after castration in mice $(\mathrm{F}(3,27)=60 \cdot 9, P<0.000001$, Table 1$)$, and decline was more pronounced than in musk shrew. Plasma androgen concentrations also fell in mice after castration (Table 1). 
Table 1. Reproductive parameters in male musk shrews and mice

\begin{tabular}{|c|c|c|c|c|}
\hline $\begin{array}{l}\text { Weeks after } \\
\text { castration }\end{array}$ & Species & $\begin{array}{l}\text { Total androgen } \\
\text { conc. }(\mathrm{ng} / \mathrm{ml})\end{array}$ & $\begin{array}{c}\text { Epididymal } \\
\text { spermatozoa }\left(\times 10^{-6}\right)\end{array}$ & $\begin{array}{c}\text { Seminal } \\
\text { vesicle wt (g) }\end{array}$ \\
\hline 0 & $\begin{array}{l}\text { Musk shrews } \\
\text { Mice }\end{array}$ & $\begin{array}{l}2.043 \pm 0.529^{*} \\
4.633 \pm 1.629^{*}\end{array}$ & $\begin{array}{l}1 \cdot 30 \pm 0 \cdot 13^{*} \\
12 \cdot 00 \pm 1 \cdot 0^{*}\end{array}$ & $\begin{array}{r}76 \cdot 2 \pm 7.5^{*} \\
238.5 \pm 24 \cdot 4^{*}\end{array}$ \\
\hline 2 & $\begin{array}{l}\text { Musk shrews } \\
\text { Mice }\end{array}$ & $\begin{array}{l}0.101 \pm 0.009 \\
0.052 \pm 0.003\end{array}$ & $\begin{array}{l}0.36 \pm 0.07 \\
0.14 \pm 0.06\end{array}$ & $\begin{array}{l}29 \cdot 2 \pm 2 \cdot 1 \\
41 \cdot 2 \pm 2 \cdot 6\end{array}$ \\
\hline 4 & $\begin{array}{l}\text { Musk shrews } \\
\text { Mice }\end{array}$ & $\begin{array}{l}0.109 \pm 0.006 \\
0.043 \pm 0.003\end{array}$ & $\begin{array}{l}0.05 \pm 0.02 \\
0.02 \pm 0.01\end{array}$ & $\begin{array}{l}30 \cdot 0 \pm 1 \cdot 1 \\
24 \cdot 5 \pm 1 \cdot 4\end{array}$ \\
\hline 6 & $\begin{array}{l}\text { Musk shrews } \\
\text { Mice }\end{array}$ & $\begin{array}{l}0 \cdot 100 \pm 0.007 \\
0.044 \pm 0.005\end{array}$ & $\begin{array}{l}0.08 \pm 0.04 \\
0.13 \pm 0.12\end{array}$ & $\begin{array}{l}14 \cdot 7 \pm 1 \cdot 3 \\
24 \cdot 5 \pm 1 \cdot 0\end{array}$ \\
\hline
\end{tabular}

Values are mean \pm s.e. for $6-7$ animals.

$* P<0.0000$ l (at least) compared with all values after castration.

\section{Discussion}

The results clearly demonstrate that epididymal spermatozoa can persist for several weeks after castration in the male musk shrew. However, it is not at all clear whether this sperm storage is androgen-independent as claimed previously by Bedford (1979). Relative to male mice, normal precastration concentrations of plasma androgens are low in the musk shrew, and yet, after castration, musk shrews have 2-fold higher plasma concentrations of androgen than do mice. Presumably this androgen is of adrenal origin. Thus, the net decrease in androgen concentrations caused by castration is less in the musk shrew than it is in the mouse. An alternative explanation to the 'androgenindependent' hypothesis is that some subset of the original spermatozoa can be maintained after castration by adrenal androgens in this species. The fact that an anti-androgen, flutamide, caused immobility and fragmentation of epididymal spermatozoa in a closely related sub-species of musk shrew (Singh, 1984) provides indirect evidence of the role of androgens in sperm storage in this animal. It is also possible that androgen sensitive target tissues such as the epididymis and seminal vesicles are more sensitive to steroids in musk shrews than they are in mice.

It has yet to be determined whether the stored spermatozoa present after castration are functional. Bedford's (1979) unpublished data mention that epididymal spermatoza were present and motile for up to 21 days after castration. In the present report only 2 of 7 animals had motile spermatozoa at 2 weeks after castration. A lack of motility suggests, but does not prove, that viability may have been impaired.

If the male musk shrew can store epididymal spermatozoa in the face of lowered androgen concentrations it is of interest to speculate on the adaptive significance of this gamete storage. Among mammals, the best examples of long-term sperm storage are in various species of bats (Gustafson, 1979). In some species of hibernating male bats, spermatogenesis occurs in the summer and mating takes place several months later, when plasma androgen concentrations have declined. Male bats therefore exhibit maximal copulatory behaviour at a time of year when blood androgen values are not at their peak (Gustafson \& Shemesh, 1976; Crews, 1984). In many species of bats in which male sperm storage is found, female sperm storage is also present. After insemination, sperm storage can occur in the female reproductive tract for several months before ovulation (Oxberry, 1979; van der Merwe \& Rautenbach, 1987).

Reproductively mature male musk shrews with testicular spermatozoa are found at all times of the year in the wild (Harrison, 1955; Louch et al., 1966). However, no information is available on seasonal variations in androgen concentrations. In the laboratory, male musk shrews do not display copulatory behaviour after castration (Rissman, 1987), and yet spermatogenesis can occur in food-restricted pubertal animals with reduced reproductive organ weights and lowered plasma 
androgen concentrations as well as in adult males housed under short-day regimens (Rissman et al., 1987; N. Wayne \& E. Rissman, unpublished observations). Therefore, unlike the situation in the male bat, copulatory behaviour in the male musk shrew appears to require high levels of androgen and yet spermatogenesis can occur in the face of relatively low concentrations of circulating androgens. Exactly which aspects of male musk shrew reproductive physiology are androgenindependent and which are androgen-dependent have yet to be precisely determined. However, musk shrews could prove to be useful animals for investigation of unique hormone-gamete-behaviour relationships.

We thank Dr F. H. Bronson for helpful discussions of these data and Ms. Yuki Morris for technical assistance. This work was supported by NSF grant BNS 8706770 to E.F.R, NIMH Research Scientist Development Award 00135 to D.C., and NICHD Training Grant HD 07264.

\section{References}

Bedford, J.M. (1979) Evolution of the sperm maturation and sperm storage functions of the epididymis. In The Spermatozoon, pp. 7-21. Eds D. W. Fawcett \& J. M. Bedford. Urban \& Schwarzenberg, Inc., Baltimore.

Brooks, D.E. (1981) Metabolic activity in the epididymis and its regulation by androgens. Physiol. Rev. 61, 515-555.

Crews, D. (1984) Gamete production, sex hormone secretion, and mating behavior uncoupled. Horm. Behav. 18, 22-28.

Gustafson, A.W. (1979) Male reproductive patterns in hibernating bats. J. Reprod. Fert. 56, 317-331

Gustafson, A.W. \& Shemesh, M. (1976) Changes in plasma testosterone levels during the annual reproductive cycle of the hibernating bat Myotis lucifugus lucifugus with a survey of plasma testosterone levels in adult male vertebrates. Biol. Reprod. 15, 9-24.

Harrison, J.L. (1955) Data on the reproduction of some Malayan mammals. Proc. zool. Soc. Lond. 125, 445460 .

Kirton, K.T., Desjardins, C. \& Hafs, H.D. (1967) Distribution of sperm in male rabbits after various ejaculation frequencies. Anat. Rec. 158, 287-292.

Louch, C.D., Ghosh, A.K. \& Bikash, C.P. (1966) Seasonal changes in weight and reproductive activity of Suncus murinus in West Bengal, India. J. Mammal. 47, 73-78.

Orgebin-Crist, M.C., Danzo, B.J. \& Davies, J. (1975) Endocrine control of the development and maintenance of sperm fertilizing ability in the epididymis. In
Handbook of Physiology: Endocrinology, Vol. V, pp. 319-338. Eds R. O. Greep \& D. W. Hamilton. American Physiological Society, Washington, D.C.

Oxberry, B.A. (1979) Female reproductive patterns in hibernating bats. J. Reprod. Fert. 56, 359-367.

Rissman, E.F. (1987) Gonadal influences on sexual behavior in the male musk shrew (Suncus murinus). Horm. Behav. 21, 132-136.

Rissman, E.F. \& Crews, D. (1988) Hormonal correlates of sexual behavior in the female musk shrew: the role of estradiol. Physiol. Behav. 44, 1-7.

Rissman, E.F., Nelson, R.J., Blank, J.L. \& Bronson F.H. (1987) Reproductive response of a tropical mammal, the musk shrew (Suncus murinus), to photoperiod. $J$. Reprod. Fert. 81, 563-566.

Singh, S.K. (1984) Effects of flutamide on the testis and accessory sex glands of the musk shrew, Suncus murinus L. Exp. clin. Endocrinol. 84, 20-26.

van der Merwe, M. \& Rautenbach, I.L. (1987) Reproduction in Schlieffen's bat, Nycticeius schlieffenii, in the eastern Transvaal lowveld, South Africa. $J$. Reprod. Fert. 81, 4150.

Whittier, J., Mason, R.T. \& Crews, D. (1987) Plasma steroid hormone levels of female red-sided garter snakes, Thamnophis sirtalis parietalis: relationships to mating and gestation. Gen. comp. Endocrinol. 67, $33-43$.

Received 19 August 1988 